\title{
Meningkatkan Kemampuan Motorik Halus melalui Teknik Mozaik pada Anak Kelompok B di TK Perdana Bangkinang Kota
}

\section{Moh Fauziddin}

Prodi Pendidikan Guru-Pendidikan Anak Usia Dini, Universitas Pahlawan Tuanku Tambusai mfauziddin@gmail.com

Perkembangan kemampuan motorik halus anak usia dini kurang mendapatkan perhatian dari orang tua dan guru pada Lembaga PAUD. Hal ini banyak disebabkan kurangnya penguasaan orang tua dan guru terhadap cara yang tepat untuk mengembangkannya. Penelitian ini bertujuan untuk mengembangkan kemampuan motorik halus melalui teknik mozaik pada anak kelompok B TK Perdana bangkinang Kota, Kampar, Riau. Penelitian ini merupakan penelitian tindakan kelas (classroom action research) yang dilakukan secara kolaboratif dan partisipatif. Subjek dalam penelitian adalah 22 anak, yang terdiri dari 16 anak perempuan dan 6 anak laki-laki. Metode pengumpulan data yang digunakan adalah observasi dan dokumentasi. Instrumen penelitian menggunakan lembar observasi. Teknik analisis data menggunakan deskriptif kualitatif dan kuantitatif. Hasil penelitian menunjukkan bahwa teknik mozaik dapat meningkatkan kemampuan motorik halus anak kelompok B TK Perdana Bangkinang Kota. Hal ini dibuktikan pencapaian kemampuan motorik halus, anak yang berkembang sangat baik Langkah-langlah yang ditempuh dalam penelitian ini meliputi; menggunting, menempel, memegang pensil dan dan menyesuaikan warna.

Kata Kunci: teknik mozaik, motorik halus, anak usia dini

The development of fine motor skills of an early childhood gets attention from parents and teachers at PAUD Institute. This is mostly due to the lack of mastery of parents and teachers to the right way to develop it. This study aims to develop fine motor skills through mosaic techniques in children group B TK Perdana Bangkinang Kota, Kampar, Riau. This research is a classroom action research conducted collaboratively and participative. Subjects in the study were 22 children, consisting of 16 girls and 6 boys. Data collection methods used are observation and documentation. The research instrument uses an observation sheet. Data analysis techniques used descriptive qualitative and quantitative. The results showed that mosaic technique can improve the fine motor ability of children of group B TK Perdana Bangkinang Kota. This is evidenced by the achievement of fine motor skills, children who develop very well Step by step taken in this study include; cutting, sticking, holding a pencil and adjusting the color.

Keywords: mosaics, early childhood, fine motor development 


\section{PENDAHULUAN}

Pendidian Anak Usia Dini (PAUD) merupakan jenjang Pendidikan sebelum Pendidikan Dasar dan terdiri dari Kelompok Bermain (KB), Taman Penitipan Anak (TPA), Taman Kanak-Kanak (TK) serta layanan lainnya sesuai dengan Undang-Undang Sisdiknas nomor 20 tahun 2003. Taman Kanak-Kanak merupakan layanan bagi anak yang berusia 4-6 tahun, terbagi menjadi dua kelompok usia yakni; kelompok A (usia 4-5 tahun) dan kelompok B (usia 5-6 tahun).

Pada masa usia dini yakni usia 0-6 tahun, anak mengalami masa keemasan (the golden years) yang merupakan masa dimana anak mulai peka/sensitif untuk menerima berbagai rangsangan. Masa peka pada masing-masing anak berbeda, seiring dengan laju pertumbuhan dan perkembangan anak secara individual.(Morrison, 2012) dengan artian pada masa inilah anak dapat dirangsang seluruh aspek perkembangannya agar dapat berkembang secara maksimal.

Salah satu aspek perkembangan yang distimulasi pada anak usia dini adalah fisik motorik. Perkembangan fisik motorik adalah perkembangan jasmaniah melalui kegiatan pusat saraf, urat saraf, dan otot yang terkoordinasi (Suyadi, 2011). Perkembangan fisik motorik terdiri atas dua jenis, yakni motorik kasar dan motorik halus.

Pengembangan fisik motorik merupakan salah satu perkembangan kemampuan dasar di TK. Materi kegiatan perkembangan fisik motorik mencakup kegiatan yang mengarah pada kegiatan untuk melatih motorik kasar dan halus, yang terdiri atas gerakan-gerakan jalan, lari, lompat, menempel, menggunting, melipat dan sebagainya. Perkembangan mototrik halus anak dilakukan menggunakan tangan dalam berbagai alat dan media kreatif, misalnya pensil, gunting, tanah liat, plastisin, dan lainlain. Kegiatan yang tersebut dirancang dan dilaksanakan pada proses pembelajaran pada Lembaga Pendidikan Anak Usia Dini (LPAUD).

Kemampuan motorik halus anak berbeda-beda dalam hal kekuatan maupun ketepatannya. Perbedaan ini dipenaguri oleh pola asuh orang tua dan guru. Perbedaan ini juga dipengaruhi oleh pembawaan anak dan stimulai yang didapatkannya. Lingkungan mempunyai pengaruh yang lebih besar dalam, kemampuan motorik halus anak. Lingkungan dapat meningkatkan ataupun menurunkan taraf kecerdasan anak, terutama pada masa-masa pertama kehidupannya. Setiap anak mampu mencapai tahap perkembangan kemampuan motorik halus yang optimal asal mendapatkan stimulasi tepat. Di setiap fase, anak membutuhkan rangsangan untuk mengembangkan kemampuan mental dan motorik halusnya. Semakin banyak yang dilihat dan didengar anak, semakin banyak yang ingin diketahuinya. Jika kurang mendapatkan rangsangan anak akan bosan. Walaupun demikian pengaruh pembawaan sejak lahir juga memiliki kontribusi terhadap cepat lambatnya kemampuan motorik halus anak.

Rancangan kegiatan yang dilaksanakan untuk mengembangkan kemampuan motorik halus anak, membutuhakn keterampilan. Keterampilan yang mencakup pemanfaatan dengan alat-alat atau media untuk kegiatan pembelajaran misalnya menggunting, menempel, menulis, menggambar, dan lain-lain. Kegiatan-kegiatan yang mencakup pemanfaatan tersebut, misalnya dengan teknik mozaik. Menurut (Sumanto, 2005) bahwa kreativitas mozaik bagi anak TK adalah kemampuan berolah senirupa yang diwujudkan dengan keterampilan merekatkan bagian- bagian bahan alam atau bahan buatan ukuran kecil-kecil sampai menutup kertas gambar yang digunakan sebagai bidang dasarnya. Gambar dengan teknik mozaik merupakan salah satu teknik menempel yang anak tidak diberi tugas untuk menggambar secara langsung, melainkan tugas anak adalah membuat bentuk gambar sesuai dengan pola yang disediakan, dan menempel dari berbagai media. Teknik mozaik pada anak TK adalah bagaimana menjiplak pola, yaitu memegang pensil, menebalkan sesuai garis, dan menyelesaikan garis pola. Menggunting pola, yaitu memegang gunting dengan benar, menggunting sesuai garis dan 
menggunting dengan rapi. Menempel pola, yaitu memberi lem pada pola, menempel pola dan menyelesaikannya.

Dengan demikian maka dapat disimpulkan bahwa teknik mozaik adalah salah satu teknik yang dapat dikembangkan untuk memberikan stimulasi terhadap perkembangan kemampuan motorik halus anak usia dini. Dalam kegiatan mozaik terhadap unsur gerakan ringan anak dalam ketepatan dalam menjiplak sesuai dengan pola, menggunting sesuai pola, gerakan menempelkan kepingan atau potongan sesuai dengan pola yang sudah disiapkan. Kegiatan ini membutuhkan ketepatan dan kecermatan anak. Proses pembuatan mozaik diobservasi dan dievaluasi yang selanjutnya dianalisa untuk mengetahui perkembangan kemampuan motorik halus anak.

Berdasarkan dari pengamatan awal di TK Perdana Bangkinang Kota Kabupaten Kampar, bahwa perkembangan fisik motorik halus anak kelompok B masih rendah. Hal ini disebabkan kurangnya media/alat dalam pengembangan motorik halus anak, disamping itu guru yang ada belum menguasai teknik mengambangkan motorik halus anak. Dari hasil wawancara dengan guru kelas kelompok B didapatkan bahwa perlu perbaikan pembelajaran pada pengembangan kemampuan motorik halus anak. Oleh karena itu peneliti berupaya berkolaborasi dengan guru kelas untuk meningkatkan kemampuan motorik halus anak dengan menggunakan teknik mozaik.

\section{KAJIAN TEORI}

\section{Pengertian Motorik Halus Anak}

Yudha M. Saputra (Saputra, 2005) menjelaskan Bahwa pengertian motorik halus adalah kemampuan anak beraktivitas dengan menggunakan otot-otot halus seperti menulis, meremas, menggenggam, menggambar, menyusun balok dan memasukkan kelereng. Sedangkan (Zulkifli L., 2005) menyatakan bahwa motorik halus adalah aktivitas yang menggunakan gerak otot-otot kecil, seperti menggerakkan jari-jari tangan. Perkembangan otot kecil, kadang-kadang disebut aktivitas motor halus, mengacu pada gerakan-gerakan yang memerlukan ketepatan dan ketangkasan, misalnya mengancingkan baju atau menutup risleting celana. Unsur yang menentukan gerakan motorik halus yaitu otot, saraf, dan otak.

Lebih lanjut ditegaskan oleh Ahmad Susanto bahwa disebut gerakan halus, bila hanya melibatkan bagian-bagian tubuh tertentu saja dan dilakukan oleh otot-otot kecil, karena itu tidak begitu memerlukan tenaga. Namun begitu gerakan halus ini memerlukan koordinasi yang cermat. Contoh gerakan halus, yaitu: (a) gerakan mengambil sesuatu benda dengan hanya menggunakan ibu jari dan telunjuk tangan (b) gerakan memasukkan benda kecil ke dalam lubang, (c) membuat prakarya (menempel, menggunting, (d) menggambar, mewarnai, menulis, menghapus, dan (e) merobek kertas kecil-kecil, meremas- remas busa dan lain-lain. (Ahmad, 2011)

Dengan demikian dapat dijelaskan bahwa motorik halus adalah gerakan halus yang ditimbulkan oleh otot-otot kecil yang dapat menimbulkan gerakan yang memerlukan ketangkasan dan ketepatan. Gerakan pada motorik halus tidak membutuhkan banyak tenaga, namun membutuhkan ketelitian dan kecermatan dalam melakukannya.

\section{Ruang Lingkup Motorik Halus}

Perkembangan motorik halus sangat penting dalam perkembangan keterampilan anak secara keseluruhan. Menurut Nuraeni (Nuraeni, 1997) latihan motorik halus pada anak adalah latihan menggerakkan otot-otot jari-jari tangan untuk beraktivitas dengan koordinasi mata di saat mengambil dan memindahkan suatu benda.

Ruang lingkup motorik halus menurut Kartono Mohamad kemampuan motorik halus meliputi: Menyusun beberapa balok menjadi beberapa menera, Memakai kaos kaki, sepatu sendiri dengan hasil kurang sempurna, Melakukan kegiatan dengan satu tangan seperti mencoret-coret, Menggambar garis lurus serta lingkaran tak beraturan, Menggengam pensil, Menggunting dengan hasil yang sempurna, 
Mengancingkan baju dan resleting, Memakai baju lengkap sendiri, Menggunakan gunting dengan baik meski belum lurus, dan Memasukan benang ke dalam jarum. (Kartono, 1992)

Motorik halus ini tidak membutuhkan tenaga seperti motorik kasar yang lebih menguras tenaga karena mebutuhkan gerak seluruh badan dan membutuhkan lebih banyak energi. Namun pada motorik halus hanya membutuhkan koordinasi antara mata dan tangan. Apabila perkembangan motorik halus anak telah optimal maka anak dapat lebih berkreasi, seperti menggunting kertas, menggambar, mewarnai, melipat serta menganyam. (Hasanah \& Silawati, 2015) . Dengan kata lain motorik halus terkait dengan hal-hal yang tidak membutuhkan tenaga dalam jumlah yang banyak, bahkan jika tenaga yang dikeluarkan berlebihan bias jadi motorik halus anak malah kurang maksimal.

\section{Fungsi Motorik Halus}

Menurut Yuliani Nurani Sujiono menegaskan bahwa fungsi pengembangan motorik halus di Taman Kanak-kanak adalah sebagai alat untuk: (a) melatih ketelitian dan kerapian, (b) mengembangkan fantasi dan kreativitas, (c) memupuk pengamatan, pendengaran dan daya pikir (d) melatih motorik halus anak, (e) mengembangkan imajinasi anak, (f) mengenalkan cara mengekspresikan diri melalui ciptaannya dengan menggunakan teknik yang telah dikuasai, dan (g) melatih kerjasama dan tenggang rasa dengan teman. (Yuliani, Nuraini, 2007)

Selanjutnya Hurlock mencatat beberapa alasan tentang fungsi perkembangan motorik bagi konstelasi perkembangan individu, yaitu: pertama melalui keterampilan motorik, anak dapat menghibur dirinya dan memper-oleh perasaan senang. Seperti anak merasa senang dengan memiliki keterampilan memainkan boneka, melempar dan menangkap bola atau memainkan alat- alat mainan lainnya. Kedua melalui keterampilan motorik, anak dapat beranjak dari kondisi helpessness (tidak berdaya) pada bulanbulan pertama kehidupannya, ke kondisi yang independence (bebas, tidak bergantung). Anak dapat bergerak dari satu tempat ke tempat lainnya, dan dapat berbuat sendiri untuk dirinya. Kondisi ini akan menunjang perkembangan self confidence (rasa percaya diri). Ketiga melalui keterampilan motorik, anak dapat menyesuaikan dirinya dengan lingkungan sekolah (school adjustment). Pada usia pra sekolah (taman kanak-kanak) atau usia kelas awal sekolah dasar, anak sudah dapat dilatih menggambar, melukis, baris berbaris, dan persiapan menulis.(PAUD Jateng, 2015)

\section{Tujuan Pengembangan Motorik Halus}

Menurut Yudha Saputra, tujuan pengembangan motorik halus menurut adalah (a) mampu memfungsikan otot-otot kecil seperti gerak jari tangan, (2) mampu mengkoordinasi kecapatan tangan dengan mata, dan (c) mampu mengendalikan emosi. Anak yang terampil dan menguasai gerakan motoriknya umumnya memiliki fisik yang sehat lantaran banyak bergerak. (Saputra, 2005) Sedangkan menurut Nofra Candra Lovia pengembangan motorik halus untuk anak usia dini yaitu: Sebagai alat untuk pengembangan keterampilan gerak kedua tangan, anak dapat menciptakan suatu hasil karya yang orisinil dari anak tersebut, sebagai alat untuk pengembangan koordinasi kecepatan tangan dan kecepatan mata, untuk menyeimbangkan penglihatan pada saat seorang guru menggunakan metode demontrasi dalam pengembangan motorik halus anak, sebagai alat untuk melatih penguasaan emosi anak, karena dalam membuat hasil karya untuk anak usia dini sangat menguras emosi anak karena pada dasrnya egosentrisnya sangat tinggi. (Lovia, 2012)

Berdasarkan uraian di atas, dapat ditegaskan bahwa tujuan pengembangan motorik halus adalah membantu mengembangkan berbagai potensi anak baik psikis dan fisik yang meliputi moral dan nilai-nilai agama, sosial emosional, kognitif, bahasa, fisik/motorik, kemandirian, dan seni untuk memasuki pendidikan dasar.

Dalam mengembangkan motorik halus anak usia dini harus juga mempertimbangkan prinsip pengembangan motorik halus anak usia dini. Adapun prinsip untuk pengembangan motorik halus, 
meliputi kematangan saraf, proses perkembangan fosiologis manusia berlangsung secara berurutan, kematangan motorik ini memotivasi untuk melakukan aktifitas motorik dalam lingkup yang luas, dan mencapai kematangan untuk terlihat secara aktif dalam aktifitas fisik.

\section{Metode Pengembangan Motorik Halus}

Pada dasarnya pembelajaran fisik motorik di TK dilaksanakan dalam batas-batas dan aturan pengembangan pra-skolastik atau pra-akademik. Bidang pengembangan fisik motorik di TK dilakukan melalui kegiatan bermain yang menyenangkan. Dengan bermain anak-anak dapat mengekpresikan berbagai perasaan maupun ide-ide yang cemerlang tentang berbagai hal yang dapat merangsang pola perkembangan kreativitas alami. (Alfiah, 2014)

Setiap anak mampu mencapai tahap perkembangan motorik halus yang optimal asal mendapatkan stimulasi tepat. Jika kurang mendapatkan rangsangan maka anak akan merasa bosan. Tapi bukan berarti kita dapat memaksanya dengan cara mengancam, membiarkan anak dalam tekanan serta hukuman. (Hasanah \& Silawati, 2015)

Anak dapat diberikan kegiatan yang dapat mengembangkan aspek perkembangan motoriknya, terutama dalam perkembangan motorik halusnya. Contohnya berikan permainan yang menarik, suatu hal baru yang belum pernah anak lihat atau alami seperti mozaik, berawal dari kertas kemudian diberi pola, kemudian ditempelkan kepingan atau potongan kertas atau bahan laiinya dan disulap menjadi sebuah bentuk gambar yang indah

Sedangkan menurut Nofra Candra Lovia pengembangan motorik halus anak dapat dikembangkan dengan metode sebagai berikut; pemberian tugas, dan praktik langsung. (Lovia, 2012) Perkembangan pada aspek ini dipengaruhi oleh kesempatan anak untuk belajar dan berlatih. Kemampuan menjiplak pola, menggunting pola dan menempel pola mozaik termasuk contoh gerakan motorik halus.

Dari paparan dapat disimpulkan bahwa metode pengembangan motorik halus pada anak usia dini dapat dilakukan dengan pemberian tugas, dan praktik langsung diramu dengan proses pembelajaran yang menyenangkan sehingga anak nyaman dan dapat melakukan kegiatan dengan baik. Kemampuan menjiplak pola, menggunting pola dan menempel pola mozaik termasuk contoh gerakan untuk mengembangkan kemampuan motorik halus anak usia dini.

\section{Unsur-unsur Perkembangan Motorik Halus}

Kemampuan motorik halus adalah kemampuan yang berhubungan dengan keterampilan fisik yang melibatkan otot kecil dan koordinasi mata dan tangan. Saraf motorik halus ini dapat dilatih dan dikembangkan melalui kegiatan dan rangsangan yang kontinu secara rutin. Seperti, bermain puzzle, menyusun balok, memasukan benda ke dalam lubang sesuai bentuknya, membuat garis, melipat kertas dan sebagainya. Kecerdasan motorik halus anak berbeda-beda. Dalam hal kekuatan maupun ketepatannya. perbedaan ini juga dipengaruhi oleh pembawaan anak dan stimulai yang didapatkannya. Lingkungan (orang tua) mempunyai pengaruh yang lebih besar dalam kecerdasan motorik halus anak. Lingkungan dapat meningkatkan ataupun menurunkan taraf kecerdasan anak, terutama pada masa-masa pertama kehidupannya. (Arifah, 2014)

Setiap anak mampu mencapai tahap perkembangan motorik halus yang optimal asal mendapatkan stimulasi tepat. Di setiap fase, anak membutuhkan rangsangan untuk mengembangkan kemampuan mental dan motorik halusnya. Semakin banyak yang dilihat dan didengar anak, semakin banyak yang ingin diketahuinya. Jika kurang mendapatkan rangsangan anak akan bosan. Tetapi bukan berarti orang tua boleh memaksa anak. Tekanan, persaingan, penghargaan, hukuman, atau rasa takut dapat mengganggu usaha dilakukan anak. 


\section{Teknik Mozaik}

\section{Pengertian Mozaik}

Mozaik adalah seni dekorasi bidang dengan kepingan bahan keras berwarna yang disusun dan ditempelkan dengan perekat. (Pusat Bahasa, 2008). Mely Novikasari menjelaskan Pengertian Mozaik yaitu pembuatan karya seni rupa dua atau tiga dimensi yang menggunakan material atau bahan dari kepingan-kepingan yang sengaja dibuat dengan cara dipotong-potong atau sudah dibentuk potongan kemudian disusun dengan, ditempelkan pada bidang datar dengan cara dilem. Kepingan benda-benda itu, antara lain: kepingan pecahan keramik, potongan kaca, potongan kertas, potongan daun, potongan kayu. Untuk membuat garis kontur yang membatasi ruangan atau bidang tidak menggunakan pewarna yang dioleskan, tetapi menggunakan tempelan-tempelan yang berbeda warna.(Novikasari, 2012)

Mozaik pada umumnya masih dianggap seni lukis lama di samping siftanya yang dua dimensi, masih dibantu dengan gambar pada proses pembuatan polanya walaupun bahannya digunakan kertas, daun, biji-bijian, kepingan kaca, pecahan keramik dan lain-lain. Mozaik dibuat dari bahan- bahan yang sifatnya leparan atau kepingan yang kemudian ditempel pada bidang datar sehingga menjadi sebuah gambar. Mozaik dapat diwakili ide dahulu, setelah ditentukan idenya kemudian cari bahannya baru menentukan idena karna harus berfikir bagaimana caranya memadukan bahan- bahan yang bermacammacam menjadi karya. (Novikasari, 2012)

Dengan demikian dapat dikatakan bahwa Mozaik adalah pembuatan karya seni rupa dua atau tiga dimensi dengan cara menempelkan potongan-potongan kertas, kayu ataupun benda lain dalam sebuah pola yang dibuat sedemikian rupa sehingga menjadi karya seni yang indah. Dalam pembuatan mozaik dibutuhkan ketangkasan dan kecermatan dalam menempelkan, memadukan warna dan menyesuaikan potongan sesuai dengan pola yang sudah disiapkan sebelumnya. Pada pembelajaran di TK praktik pembuatan mozaik sangat bagus digunakan untuk mengembangkan berbagai aspek perkembangan anak usia dini, utamanya aspek kemampuan motorik halus.

\section{Material Mozaik}

Mengingat mozaik yang akan diterapkan sasarannya adalah untuk anak usia dini, bahan harus di pertimbangakan, diantaranya : ramah untuk anak, tidak berbahaya untuk anak, tidak mengandung zat racun, tidak berasal dari benda tajam yang mudah merugikan untuk anak seperti pecahan kaca.(Masnonok, 2017).

Mengenai persiapan materialnya mozaik lebih mudah, karena terdiri dari satu jenis bahan material pokoknya. Material pembuat mozaik dapat dibedakan menjadi dua jenis (Novikasari, 2012), yaitu: (a) material mozaik dalam pengertian umum, pada umumnya adalah karya seni yang menginginkan estetika dan memiliki tujuan praktisi yaitu untuk kepentingan terapan, karya mozaik sering dipakai untuk hiasan dinding, pintu, sopi-sopi rumah, dan perangkat mebeler. Pada seni modern tentang mozaik di Jepang yang telah dikenal secara umum yaitu Patchwork and Quilting. (b) Material Mozaik untuk Pembelajaran di Taman Kanak-Kanak. Tentu akan berbeda material yang dipakai untuk karya mozaik dengan yang dipakai pada umumnya. Karena mozaik bagi anak TK merupakan media pengungkap ide estetika, bukan untuk pembuatan mozaik yang memiliki nilai praktis. Ada beberapa contoh material yang dipakai untuk pembelajaran mozaik di tingkat TK, antara lain: kertas, kancing baju, potongan kain, biji-bijian, daun kering, potongan kayu, potongan tripleks uang kecil-kecil, biji korek api, dan lainnya karena seni mozaik itu sangat banyak bahannya, yang utama adalah kreativitas anda memilih dan mengajak siswa untuk berekspresi dengan media yang anda tentukan.

Bahan yang berwarna mencolok seperti kertas asturo sangat disukai anak. Warnanya yang mencolok serta mudah dibentuk menjadi salah satu daya tarik dalam pembuatan mozaik. Bahan alam seperti daun pisang kering, daun ketela kering serta daun lainnya, juga dapat digunakan dalam pembuatan mozaik, . Bahan tersebut mudah didapatkan di lingkungan sekolah maupun lingkungan anak apabila mereka ingin 
membuatnya dirumah. Disamping itu biji-bijian juga tak kalah menarik apabila digunakan sebagai bahan pembuatan mozaik. Bentuknya yang bermacam-macam, warna beragam serta tekstur yang berbeda-beda, apabila dipadukan dengan baik akan menghasilkan karya yang sangat indah.

Penggunaan lem sebagai salah satu komponen pembuatan mozaik, dipilih dan digunakan dengan mempertimbangkan prinsip ; aman, mudah digunakan, mudah dibersihkan dan mudah didapatkan serta tidak mahal.

Dengan demikian dapat dikatakab bahwa kemampuan guru dalam memilih dan menyiapkan bahan yang akan digunakan merupakan salah satu kunci berhasilnya pembelajaran dengan menggunakan teknik mozaik. Pada prinsipnya bahan yang digunakan hendaknya mudah didapatkan, warna yang disukai oleh anak dan mudah digunakan oleh anak, dan menghasilkan karya mozaik yang indah.

\section{Fungsi Mozaik}

Pada dasarnya mozaik mempunyai tiga fungsi yaitu ; pertama, Fungsi Praktis artinya karya seni rupa mozaik selain bersifat induvidual juga sebagai media ekpresi buat anak. Kedua, Fungsi Edukatif artinya melalui penerapan metode pembelajaran melalui pendidikan seni mozaik dalam upaya untuk membantu pengembangan berbagai fungsi perkembangan dalam diri seorang anak, yang meliputi kemampuan : fisik, daya pikir, daya serap, emosi, cita rasa keindahan, kreativitas. Ketiga, Fungsi Ekspresi artinya unsur-unsur seni rupa pada karya mozaik seperti garis, warna, benruk dan tekstur merupakan bahasa rupa yang digunakan dalam cara mengungkapkan ide-ide atau gagasan, imajinasi, pengalaman yang estetis yang kemudian diungkapkan berwujud ekspresi simbolis yang sangat pribadi.

\section{Proses Kreasi Mozaik pada Anak Usia Dini}

Anak usia dini memiliki potensi yang dapat dikembangkan. Salah satunya adalah potensi seni. Dalam melakukan kegiatan teknik mozaik dapat mengembangkan seni dan kreatifitas anak. Lebih lanjut (Novikasari, 2012) menyatakan proses kreasi atau proses kreatif merupakan tahapan yang harus dilalui oleh seseorang dalam suatu karya seni yang dalam hal ini adalah kolase, mozaik, dan montase. Mulai dari proses memperoleh, dan menemukan sumber ilham atau inspirasi, gagasan hingga proses mewujudkan dalam karya kolase, mozaik, dan montase. Dalam hali ini impresi yang dirasakan, dipikirkan, dan dihayati oleh seseorang dituangkan sebagai ekspresi yang personal dalam wujud karya kolase, mozaik, dan montase.

Kreasi dalam pembuatan karya tersebut melalui tahapan-tahapan, yaitu: tahap rasa, tahap karsa, tahap cipta dan tahap karya.(Novikasari, 2012) Keempat tahapan tersebut harus dilalui anak dalam kegiatan pembuatan mozaik.

\section{Teknik Mozaik}

Mozaik terdiri dari dua dimensi dan tiga dimensi, tetapi prinsip kerjanya sama, yaitu menempelkan potongan benda-benda lain. Benda-benda tersebut dapat berupa pecahan kaca, pecahan keramik, potongan kayu, batu, gunting, kertas, guntingan dari daun kering, dan lain sebagainya selama masih berbentuk potongan yang lembarnya dapat disusun dalam bidang yang telah disediakan. (Novikasari, 2012)

Teknik pewarnaan pada mozaik ini dipilih dari bahan/material mozaik yang akan di tempel yang memiliki warna asli, artinya warna tersebut asli dari warna kaca, mika, keramik, daun, kayu, sehingga nantinya tidak perlu menambahkan pewarnaan setelah ditempelkan. Untuk menghasilkan corak gambar yang elastis atau dekoratif, maka anda harus mengatur warnanya tersebut dari susunan materialnya. Lebih lanjut (Novikasari, 2012) memaparkan salah satu contoh pembuatan mozaik adalah ; Siapkan kertas karton/kertas tebal yang diberi pola atau motif gambar. Karena bahan dasarnya dari karton atau kertas lain, maka materialnya yang ditempelkan adalah potongan kertas, daun, rumput kering, plastik, 
kemudian tempelkan dengan menggunakan lem disusun menurut tujuan gambar yang diinginkan. Kemudian Untuk material seperti kaca, kayu, keramik, batu, biasanya ditempelkan pada dinding, tembikar, lantai atau papan yang diperuntukan untuk hiasan mozaik.

teknik mozaik adalah membuat pola geometris yang materialnya terbuat dari kertas karton asturo berwarna, kemudian ditempel menggunakan lem dan disusun menurut pola. Dengan teknik-teknik yang dilakukan dalam mozaik, seperti mengelem dan mewarnai dibutuhkan kemandirian anak dan kecermatannya dalam membuat mozaik. Kemandirian di mana anak mampu melakukan dengan percaya diri dan dalam prosesnya tidak sering membutuhkan bimbingan guru, dan kecermatan merupakan ketepatan anak dalam membuat dan menempel bentuk geometris. (Arifah, 2014)

Dari paparan diatas dapat dikatakan bahwa, teknik mozaik terdiri dari teknik menempelkan potongan atau kepingan bahan yang telah disiapkan, teknik pemilihan warna yang digunakan, dan teknik pemilihan motif atau pola. Teknik mozaik yang digunakan dalam penelitian ini adalah; menjiplak pola yang disiapkan, menggunting pola, dan menempelkan kepingan atau potongan bahan pada pola yang sudah disiapkan.

\section{Kelebihan dan Kekurangan Teknik Mozaik}

kelebihan dari teknik mozaik adalah (a) dapat mengembangkan kreativitas, emosi, sosial, dan kemampuan motorik halus anak, (b) alat dan bahan mudah didapat, (c) mudah dimengerti dan dikerjakan oleh anak, (d) melatih konsentrasi, kesabaran dan kemandirian anak, dan (e) memiliki tampilan yang berwarna dan atraktif, sehingga menarik buat anak. Kelemahan dari teknik mozaik adalah memerlukan waktu yang lama, sehingga dikhawatirkan anak menjadi cepat bosan. (Arifah, 2014)

\section{METODE PENELITIAN}

Desain penelitian yang dilakukan dalam studi ini adalah Penelitian Tindakan Kelas (PTK). Rancangan penelitian ini akan dilaksanakan dalam dua siklus dan pada masing-masing siklus tersebut terdiri dari dua pertemuan. Model penelitian tindakan kelas yang dilaksanakan dalam penelitian ini yaitu mengacu pada model yang dikembangkan oleh John Elliot. Model Elliot digunakan dalam penelitian ini, karena pada dasarnya untuk menigkatkan proses pembelajaran khususnya perkembangan motorik halus pada anak perlu dilakukan secara berulang-ulang, hal ini sejalan dengan model Elliot yang terdiri dari dua siklus dan masing-masing siklus terdiri dari dua tindakan, jadi tindakan yang dilakukan terdiri dari empat tindakan.

Dalam penelitian ini, jenis penelitian tindakan yang digunakan dalam adalah penelitian tindakan kelas kolaboratif, yaitu kerjasama antara guru dan peneliti. Peneliti dan guru menyiapkan instrumen evaluasi/observasi, ikut terlibat dalam pembelajaran dan dalam perencanaan tindakan yang akan dilaksanakan, serta melaksanakan pembelajaran sesuai dengan skenario yang sudah disiapkan bersama.

Penelitian tindakan kelas ini dilaksanakan dikelompok B TK Perdana Bangkinang Kota yang terdiri dari 22 anak, 16 anak perempuan dan 6 anak laki-laki. TK Perdana Jalan Raya Ridan Permain 23 Bangkinang Kota, Kabupaten Kampar, Riau.

Instrumen penelitian digunakan oleh peneliti untuk memperoleh data yang akurat dan sesuai dengan permasalahan yang akan diteliti. Adapun instrumen digunakan dalam penelitian ini meliputi pedoman penilaian proses, pedoman observasi, pedoman wawancara, pedoman catatan lapangan dan dokumentasi.

Untuk mengetahui keefektifan dalam kegiatan pembelajaran perlu dilakukan analisis data.Adapun teknik analisis data yang akan digunakan pada penelitian ini adalah teknik pengumpulan kualitatif dan kuantitatif. Data kualitatif adalah data yang diwujudkan dalam bentuk deskripsi. Data kualitatif 
diperoleh dari lembar penilaian proses anak, observasi, catatan lapangan, wawancara dan dokumentasi. Sedangkan Pengelohan data kuantitatif berupa angka dan dilakukan untuk mengukur dan mengetahui peningkatan kemampuan hasil belajar yang diperoleh anak selama proses pembelajaran

\section{HASIL PENELITIAN}

Penelitian dilaksanakan sebanyak 2 siklus dan setiap siklus dua kali pertemuan. Setiap pertemuan peneliti berkolaborasi dengan guru kelompok B di Taman Kanak-Kanak (TK) Perdana, mulai dari pembuatan Rencana Pelaksanaan Pembelajaran Harian (RPPH), menyiapkan bahan yang digunakan dalam proses pembelajaran dengan menggunakan teknik mozaik, instrumen penilaian anak, dan lembar observasi aktifitas anak dan guru.

Pada perencanaan Siklus 1 ini, peneliti dan guru kelas merencanakan melakukan tiga kegiatan untuk mengembangkan kemampuan motorik halus, yakni; menjiplak pola, mengguting pola dan menempel pada pola. Kegiatan ini dirancang dengan menggunakan bahan dari kertas dengan pola binatang sesuai dengan tema yang sedang berlangsung.

Saat pembelajaran berlangsung peneliti bertindak sebagai observer, mengamati aktivitas siswa dan aktivitas guru dalam melaksanakan pembelajaran kemudian dilanjutkan dengan mengevaluasi hasil pembelajaran yang telah dilaksanakan. Tampak pada proses pembelajaran anak terlihat kurang antusias dalam kegiatan mozaik. Hal ini terjadi karena sebagian besar anak masih kurang mengerti dengan kegiatan membuat mozaik. Disamping itu anak masih belum terampil memegang gunting dalam kegiatan menggunting pola. Sebagian besar orang tua anak melarang anaknya memegang benda tajam (gunting) karena dianggap berbahaya.

Berdasarkan hasil observasi dan evaluasi yang dilakukan pada siklus 1, didapatkan data sebagai berikut;

Tabel 1. Kemampuan anak dalam teknik mozaik siklus 1

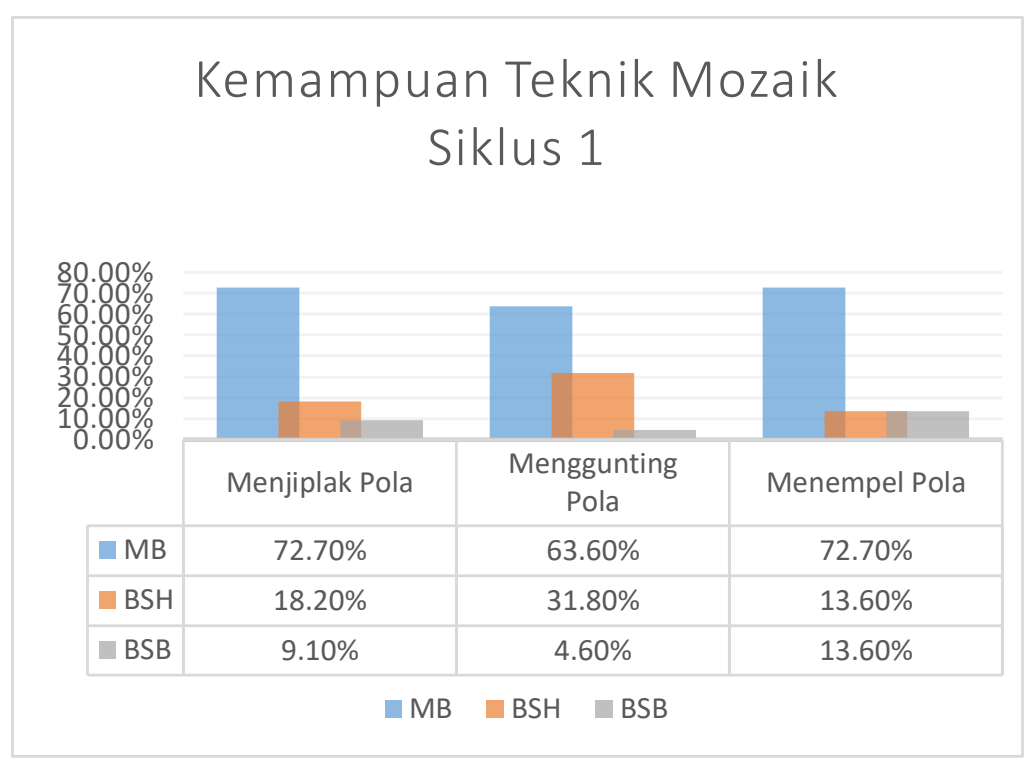

Dari tabel 1 diatas dapat diketahui bahwa masih belum ada perubahan yang signifikan dari 3 kemampuan yang diharapkan, masih dominan pada kriteria Mulai Berkembang (MB). Peneliti dan Guru melakukan refleksi terhadap hasil kegiatan pembelajaran pada siklus 1. Dari temuan yang didapat dari hasil pengisian lembar observasi siswa dan guru, serta pengamatan selama proses pembelajaran, maka akan dilakukan perbaikan pada bahan yang digunakan untuk kegiatan mozaik. Bahan dicarikan dari bahan yang lebih menarik bagi anak. Sedangkan pola yang digunakan akan dibuat lebih menarik pada 
pertemuan siklus 2. Peneliti dengan guru kelas memutuskan untuk melanjutkan ke siklus 2 sebanyak dua kali pertemuan.

Pada Perencanaan Siklus 2, peneliti dan guru kelas kembali membuat perencanaan dengan mempertimbangkan hasil refleksi pada siklus satu, yaitu; menyiapkan bahan yang menarik untuk digunakan dalam kegiatan mozaik. Dalam hal ini bahan yang disiapkan adalah kertas warna-warni asturo dan daun kering. Bahan ini diharapkan dapat lebih menarik minat anak dalam melakukan kegiatan pembelajaran dengan teknik mozaik. Sedangkan pada pola, peneliti dan guru menyiapkan pola bentuk binatang yang mudah dijumpai oleh anak-anak dalam lingkungan rumahnya. Dalam hal ini menggunakan pola gambar Ayam pada pertemuan pertama dan gambar Kambing pada pertemuan kedua. Disamping itu peneliti akan mengundang orang tua anak untuk diberikan arahan terkait pelarangan orang tua terhadap anak untuk memegang benda tajam (gunting).

Perbaikan yang direncanakan dituangkan dalam RPPH sebanyak dua pertemuan pada siklus kedua, peneliti juga menyiapkan pola dan bahan yang akan digunakan pada dua pertemuan pada siklus kedua, menyiapkan lembar observasi aktifitas siswa dan aktifitas guru.

Saat pembelajaran berlangsung peneliti menjadi observer, mengamati aktifitas anak dan guru selama dua kali pertemuan pada siklus kedua. Dari hasil pengamatan langsung yang dilakukan peneliti didapatkan bahwa anak sangat antusias melaksanakan kegiatan Selanjutnya peneliti dan guru melakukan analisa terhadap hasil observasi dan evaluasi pada siklus 2. Data yang didapatkan dapat dilihat pada tabel berikut ini;

Tabel 2. Kemampuan anak dalam teknik mozaik siklus 2

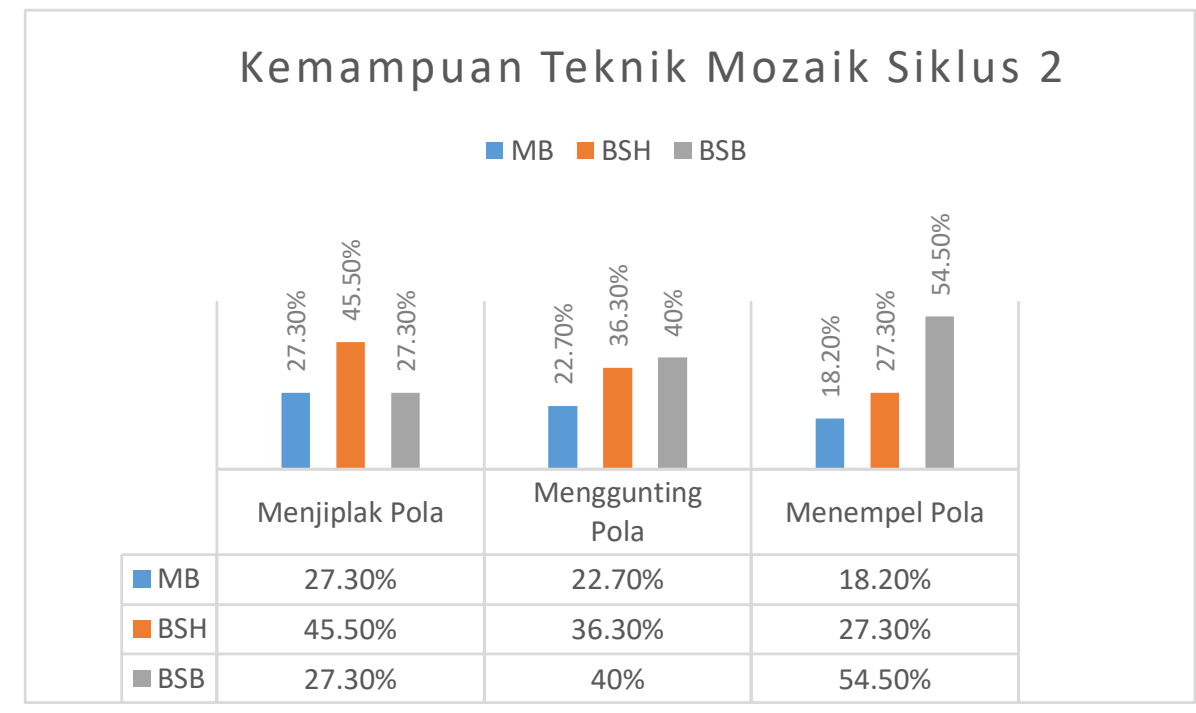

Dari tabel diatas dapat dilihat bahwa sudah terjadi perubahan signifikan kemampuan anak dalam teknik mozaik. Sebagian besar anak sudah berada pada kriteria Berkembang Sesuai Harapan (BSH) dan Berkembangan Sangat Baik (BSB). Hal ini dapat dianalisa bahwa peningkatan kemampuan teknik mozaik anak yang merupakan salah satu cara mengembangkan motorik halus anak dapat ditingkatkan dengan menggunakan material mozaik yang menarik bagi anak dan pola mozaik yang disukai oleh anak, yang pada siklus pertama belum dilaksanakan oleh peneliti dan guru kelas. 


\section{DISKUSI}

Keberhasilan dalam meningkatkan kemampuan motorik halus melalui teknik mozaik pada anak usia dini tidak lepas dari peran guru dalam mengembangkan dan memilih pola dan material yang tepat dan menarik bagi anak untuk digunakan dalam proses pembelajaran sehingga menimbulkan suasana pembeajaran yang efektif untuk mengembangkan kemampuan motorik haluas anak. Senada dengan pernyataan diatas Ririn Arifah pada hasil penelitiannya menyimpulkan langkah-langkah pembelajaran yang efektif untuk mengembangkan kemampuan motorik halus melalui teknik mozaik, meliputi: (1) membuat kertas mozaik dengan berbagai macam warna, (2) memperjelas tahapan atau langkah dalam menjiplak, menggunting dan menempel, dengan menggunakan kertas asturo dengan ukuran yang besar dan menempelkan setiap potongan mozaik di papan tulis, (3) memotivasi anak untuk bisa menyelesaikan sendiri tanpa minta bantuan orang lain baik guru maupun teman, dan (4) mengingatkan anak untuk memegang pensil, gunting dan mengoles lem dengan mempergunakan jari-jemari yang baik dan benar.(Arifah, 2014)

Tidak hanya itu, dalam proses pembelajaran guru mengkondisikan pembelajaran dengan suasana yang menyenangkan. Anak usia dini sangat menyukai hal-hal yang menarik. ciri yang paling menonjol dari anak adalah: mereka sangat cepat bosan. Detty Noviyanti dalam penelitiannya menemukan bahwa salah satu cara guru untuk meningkatkan peserta didik dalam keterlibatan aktif dalam kegiatan tersebut yaitu menyediakan beragam kegiatan yang menyenangkan seperti menonton video interaktif, membaca, menyanyi, aktivitas yang melibatkan problem solving (misalnya kuis siapa dia, petak umpet, dan lainlain), aktivitas bermain yang mampu meningkatkan kosa kata peserta didik (misalnya teka- teki, permainan komunikasi), maupun mengadakan aktivitas karyawisata.(Noviyanti, Sutini, \& Kurniawati, 2016)

Dalam pelaksanaan proses pembelajaran dengan menggunakan teknik mozaik, guru memperhatikan waktu sehingga sedapat mungkin disetting agar anak tidak merasa bosan. Jika anak terlihat bosan, guru segera mencari cara untuk membuat mereka kembali bersemangat, adakalanya dengan permainan tepuk, yel dan cara lainnya. Maria Inawati menyatakan kemampuan berkonsentrasi mereka masih sangat terbatas dan mudah terpecah perhatiannya. (Maria Inawati, 2011). Namun pada kenyataannya anak menggangap kegiatan motorik halus sebagai pelajaran yang sangat membosankan, karena sifat bermain di satu tempat dan dalam waktu lama yang dinilai masih membosankan. Selain itu proses pembelajaran yang masih berpusat pada guru turut menyumbangkan rasa kebosanan pada anak (Setiawan R, 2017).

\section{KESIMPULAN}

Kemampuan motorik halus anak sangat penting diperhatikan dan dikembangkan sejak usia dini. Salah satu cara meningkatkan kemampuan motorik halus adalah dengan teknik mozaik melalui keiatan menjiplak pola, mengunting pola dan menempel pada pola. Terbukti teknik mozaik dapat meningkatkan kemampuan motorik halus anak usia dini.

\section{DAFTAR PUSTAKA}

Ahmad, S. (2011). Perkembangan Anak Usia Dini Pengantar dalam Berbagai Aspeknya. Jakarta: Kencana Perdana Media Group.

Alfiah. (2014). Upaya Meningkatkan Kemampuan Motorik Halus Dalam. Jurnal Ilmiah PG-PAUD IKIP Veteran Semarang, 2(2), 1-9.

Arifah, R. (2014). Mengembangkan Kemampuan Motorik Halus melalui Teknik Mozaik pada Anak Kelompok A di TK ABA Khadijah Bangunjiwo TImur Kasihan Bantul. Universitas Negeri Jogjakarta.

Hasanah, D. L., \& Silawati, E. (2015). Pengembangan motorik halus anak usia dini melalui kegiatan 
origami. Jurnal Edukid, 3(2).

Kartono, M. (1992). Motorik Halus Edisi Khusus. Majalah Ayah Bunda, 21 Agustus(17).

Lovia, N. C. (2012). Pengembangan Motorik Halus Anak Usia Dini. Retrieved March 13, 2018, from http://nofracandralovia.blogspot.co.id/2012/12/pengembangan-motorik-halus-anak-usia.html

Maria Inawati. (2011). Meningkatkan minat mengenal konsep bilangan melalui metode bermain alat manipulatif. Jurnal Pendidikan, 16(Tahun ke10), 1-10. https://doi.org/10.1017/CBO9781107415324.004

Masnonok. (2017). Seni Mozaik Bagi Anak PAUD - Artikel PAUD. Retrieved March 13, 2018, from https://artikelpaud.com/seni-mozaik-bagi-anak-paud/

Morrison, G. S. (2012). Dasar dasar pendidikan anak usia dini (PAUD), 416.

Novikasari, M. (2012). Kolase, Mozaik dan Montase. Retrieved March 13, 2018, from http://melyloelhabox.blogspot.co.id/search?q=mozaik

Noviyanti, D., Sutini, A., \& Kurniawati. (2016). Pendekatan Komunikatif Interaktif untuk Meningkatkan Kosakata Anak Usia Dini 1. Program Pendidikan Anak Usia Dini, 2(4), 1-8.

Nuraeni. (1997). Intervensi Dini bagi Anak Bermasalah. Jakarta: Rineka Cipta.

PAUD Jateng. (2015). Fungsi Perkembangan Motorik Halus Anak Usia Dini - PAUD JATENG. Retrieved March 13, 2018, from https://www.paud.id/2015/09/fungsi-perkembangan-motorikhalus-anak-usia-dini.html

Pusat Bahasa. (2008). Kamus Besar Bahasa Indonesia. (D. Sugono, Ed.). Jakarta: Pusat Bahasa Departemen Pendidikan Nasional.

Saputra, Y. M. (2005). Pembelajaran Koopertif untuk Meningkatkan Keterampilan Anak TK. Yogyakarta: FIP UNY.

Setiawan, R. (2017). The Influence of Income, Experience, and Academic Qualification on the Early Chilhood Education Teachers' Creativity in Semarang, Indonesia. International Journal of Instruction, 10(4), 39-50.

https://doi.org/10.12973/iji.2017.1043a

Sumanto. (2005). Pengembangan Kreativitas Seni Rupa Anak TK. Jakarta: Departemen Pendidikan Nasional.

Suyadi. (2011). Psikologi Belajar PAUD. Suraka: UNS Press.

Yuliani, Nuraini, S. (2007). Konsep Dasar Anak Usia Dini. Jakarta: Universitas Terbuka.

Zulkifli L. (2005). Psikologi Perkembangan. Bandung: PT Remaja Rosda Karya. 